\section{DARWIN VINDICATED}

The Structure and Distribution of Coral Reefs By Charles Darwin. Originally published 1842 . Pp. xii $+214+3$ plates. (Berkeley and Los Angeles: University of California Press; London: Cambridge University Press, 1962.) 1.95 dollars; $17 s$. net.

$T$ is now more than one hundred years sinee Darwin 1 published his work on the structure and distribution of coral reefs and it is good to have this classic readily available in a well-printed paper-back.

A very wolcome foreword is contributed by Prof. H. W. Menard, who remarks: "It may be unprecedentod for an essentially correct hypothesis to be the centro of a raging controversy for moro than a hundred years". He goes on to diseuss the hypothosis of the origin of atolle by subsidence in the light of inore recont work. The Royal Society's attempt to test this theory by drilling on Funafuti Atoll had been inconclusive, but more rocent results at Eniwetok Atoll and elsowhere by drilling, supplemonted by seismic soundings, have demonstrated that subsidence has predominated for thousands of years. It has beon shown, for oxample, from seismic studies of four atolls that each has a cap of coral soveral thousand feet thick, and so Darwin's hypothesis may be taken as proved.

Prof. Menard adds: "Sprinkled among the atolls of the Western Pacific are about a hundred and fifty 'guyots' or ancient islands now submerged to depths as great as a mile. They were originally identified as former islands solely because they are truncated volcanic cones and the truncation could only be ascribed to erosion at sea level. This deduction has been amply confirmed by doep-sea dredging of guyots. The tops are covered with rounded cobbles and fossils typical of very shallow water. . . . Hormer islands in favourable locations have been capped by coral that has grown upward as fast as they subsided, and these are atolls. Other former islands, lacking the coral, are now guyots".

With Darwin vindicated, the controversy has now shifted to the much-debated question of the cause of the subsidence.

W. J. REes

\section{STAINING TECHNIQUES}

\section{Staining Animal Tissues}

Practical and Theoretical. By Edward Gurr, with a foreword by Sir Howard W. Florey. Pp. xii + $631+1$ photograph. (London: Leonard Hill (Books), Ltd., 1962.) 84s.

$\mathrm{T}$ recent years a number of books devoted to 1 collections of staining techniques has been published, so that one might question the nced at the present time for yet another such volume. The author of this work, however, has stated in his proface that he has attempted to bring together a number of such techniques and staining procedures which were previonsly scattered throughout many books and journals, so this present book does in fact form a welcome addition to the laboratory bookshelves. It is undoubtedly a gront convenience to have such compilations readily at hand.

At the same time, Mr. Gurr has devoted some ninety pages to a discussion of various aspects of the mechanism and thoory of staining reactions. Such observations are essential to a proper understanding of the rationale of microtechnique, but one must question the advisability of treating them in a practical text. Of necessity this soction must be subordinate to the main part of the book, devoted to the actual techniques thomselves, and this leads to a rather limited treatment. For myself, I would like to seo such theoretical aspects dealt with at greater length in a separate publication.

The selection of techniques given is very wide (more than 300 staining procedures and 700 recipes are included) and designed to meet the needs of workers in widely separatod fields. Each method is given in detail, and notes of spocial points are appended.

An appendix giving details of the preparation and use of various fixatives, embodding methods and mountants is a useful addition to tho main part of the book. There is, one is pleased to note, a very adoquate bibliography and a comprehensive author index and general subject index. The book is well produced, indoed, almost too well producod, as its price is rather high and this may well prevent its acquisition by some laboratorios. It is welcomed as a valuable souree of reference for the busy histologist.

S. BRADBURY

\section{SISAL HEMP}

Sisal

Twenty-five Yoars' Sisal Research. By G. W. Lock. (Tropical Science Sorios.) Pp. xvii $+355+62$ plates. (London: Longmans, Groon and Co., Ltd., 1962.) $60 s$.

CISAL, like so many tropical crops, has reached its $\checkmark$ groatest stature far from home. This hard fibre, which owes its name to the Mexican port of Sisal whence came tho early shipments, is now a major product first of East Africa, with Tanganyika by far the greatest producer, and secondly, of Brazil.

East Africa's lead, not only in bulk of shipments, but also in scientific production, owes much to the far-sighted establishment in 1934 of a research station for sisal in Tanganyika. G. W. Lock was placod in charge, and his direction of the work over a period of twenty-five years has onablod hirn to write with exceptional experience of the crop.

An introductory chapter outlines the history of sisal in East Africa, going back to seventy years ago, when an article in the Kew Bulletin inspired the Germen agronomist Hindorf to give the plant a trial in Tanganyika where ho was employed. The second chapter contains a useful account of the botany and life of the plant. From then on, the author is concerned with the practical handling of the crop, its propagation and raising in tho nursery, its establish. ment in the field, its maintenance, nutrition, and pest-control, its cropping and processing to make fibre. Throughout, the author's recommendations, whether as to choice of planting material or to spacing in the field, are backed by the results of field experiments covering most aspects of cultivation. While forming, therefore, \& very adequate manual of the growing and preparation of sisal, the work shows in intcrosting manner how ayricultural research ean serve and can shape efficiont production.

The author writes clearly and compotently, providing a good index and ample references to relovant literaturo. 'The book is well produced, with admirable illustrations, and is a welcome addition to the series of works on tropical crop-plants. T. $\Lambda$. RusseLL 